


\section{CALIFORNIA STUDIES IN URBANIZATION}

AND ENVIRONMENTAL DESIGN

THE COMMUNITY BUILDERS

by Edward P. Eichler and Marshall Kaplan

CHANDIGARH: A STUDY OF THE CITY AND ITS MONUMENTS by Norma Evenson

THE QUEST FOR REGIONAL COOPERATION: A STUDY OF THE NEW YORK METROPOLITAN REGIONAL COUNCIL

by Joan B. Aron 
American City Planning since 1890 



\section{AMERICAN Gity PLANNING SINCE 1890}

A history commemorating the Fiftieth Anniversary of the American Institute of Planners 
University of California Press

Berkeley and Los Angeles, California

University of California Press, Ltd.

London, England

Copyright $\odot 1969$, by

The Regents of the University of California

First Paperback Printing, 1971

Designed by Ikuko Workman

ISBN: 0-520-01382-4 (cloth)

$$
\text { 0-520-02051-0 (paper) }
$$

Library of Congress Catalog Card Number: 70-84533

Printed in the United States of America 
This publication was made possible by the cooperation of the University of California with the Fiftieth Anniversary Commemoration Committee of the American Institute of Planners. Of the branches of the University which contributed to the preparation of the work, the Institute of Governmental Studies provided the chief support for a period of four years.

The Department of City and Regional Planning, the Institute of Urban and Regional Development, and the Center for Planning and Development Research also aided in the undertaking. 
